\title{
FUNDOS DE PENSÃO NO BRASIL DO FINAL DO SÉCULO XX: GUERRA CULTURAL, MODELOS DE CAPITALISMO E OS DESTINOS DAS CLASSES MÉDIAS*
}

Roberto Grün

Os fundos de pensão brasileiros são o que? Modernos mecanismos que fazem parte da almejada contemporaneidade da economia nacional em relação às práticas do "Primeiro Mundo"? "Entulhos corporativos" do passado getulista que devem ser destruídos para que nossa modernidade possa emergir?

Trava-se atualmente uma luta, ao mesmo tempo econômica e cultural, cujo contencioso é justamente definir a "real natureza" (tanto do que eles são quanto do que eles realmente deveriam ser) dessas entidades, que estão presentes no panorama econômico brasileiro dos últimos trinta anos e na década de 90 entraram também na agenda política e sindical. As formas através das quais essa luta se enceta, bem como seus movimentos e seus resultados, falam muito sobre como é, e será, o Brasil moderno e as possíveis posições das classes médias nessa configuração. $O$ texto que se segue corresponde ao acompanhamento dessa disputa durante a segunda metade da década de 90 e de alguns passos mais importantes do que tem acontecido a partir de 2000.

Olhando pela lente da sua história, os fundos de pensão brasileiros realmente apresentam uma ambigüidade que os coloca em uma zona cinzenta entre os mecanismos da "velha estrutura corporativa" e os dispositivos centrais da "moderna governança econômica". De um lado, foram criados, na sua imensa maioria, no entorno das hoje execradas companhias estatais e, por causa disso, entraram na cauda do halo negativo que essas organizações padeceram no passado recente. Por outro lado, internacionalmente, o fortalecimento desse gênero de entidade é peça essencial da retórica de justificação do capitalismo moderno.

Nossos tempos "neoliberais" atualizam um contencioso cultural permanente de nossa história contemporânea, que tem por centro a definição do conceito de "moderno". Entre os diversos efeitos sociais dessa nominação, um dos maiores é o que confere aos atores o direito de falarem 
e serem ouvidos na arena pública, com os evidentes reflexos que esse poder exerce sobre a autoconfiança e demais operações que tornam os indivíduos mais ou menos capazes de exercerem a violência simbólica ou serem suscetíveis a ela ${ }^{1}$. Esse conflito tem peculiaridades e adquire uma agudeza ímpar no seio das classes médias brasileiras, que precisam fazer frente a enormes desafios para manter ou elevar seu status relativo na nossa sociedade. Há uma enorme dificuldade em afirmar quais seriam as boas decisões que assegurariam o bem-estar presente e futuro dos indivíduos e de sua descendência. Aparentemente, o exemplo do passado não serve mais para indicar os passos óbvios a serem dados para o bom encaminhamento na sociedade, e ainda que haja uma imagem abstrata dos contornos do futuro e, portanto, das possíveis formas de inserção nele, estamos longe de poder apontar com segurança a localização exata das oportunidades disponíveis.

As oportunidades corporificam-se em instituições, como nossos fundos de pensão, que são constantemente reproduzidas. Evidentemente, esses processos estão longe de ser socialmente neutros. Em torno deles, trava-se uma verdadeira guerra cultural com ganhadores e perdedores bem tipificados, e a partir dessa configuração podemos ter acesso a diversas reacomodações dos segmentos de classe média na estrutura so$\mathrm{cial}^{2}$. No caso dos fundos de pensão, vemo-nos diante do processo de decadência recente de um setor do antigo funcionalismo público que se renovou na Revolução de 1964. Naquele momento, diversas repartições públicas cedem lugar às empresas públicas, que então se apresentavam como entidades dinâmicas, capazes de superar os entraves que impediam a boa prestação de serviços. No contexto daquela transformação, a antiga aposentadoria funcional garantida pelo Tesouro nacional e estaduais foi substituída pelos fundos de pensão, que deveriam ser seus equivalentes funcionais modernos. O debate nacional que se deflagrou a partir de 1976, com a discussão sobre os excessos do setor estatal caracterizados como "as mordomias", iniciou a decadência da legitimidade de todo aquele grupo de empresas e agências ${ }^{3}$. Daí em diante, o conjunto formado pelas empresas públicas e demais agências estatais é cada vez mais intensamente questionado como fonte de progresso e de bem-estar da sociedade, enquanto as empresas e agências engendradas no espaço da economia privada ou privatizadas adquirem a imagem de agentes do futuro desejado pela sociedade brasileira ${ }^{4}$. 


\section{Os fundos na organização do capitalismo}

Os fundos de pensão adquiriram uma saliência muito grande na cena econômica brasileira e, internacionalmente, sempre são lembrados como instituições importantes na "governança" do capitalismo contemporâneo. Se acompanharmos as discussões econômicas e políticas atuais em diversos países da comunidade econômica européia, verificaremos que o debate em torno dos fundos de pensão se constitui justamente em um dos pontos centrais de clivagem entre projetos políticos e econômicos alternativos. Os grupos mais favoráveis ao "modelo anglo-saxão" de capitalismo são seus proponentes, enquanto aqueles mais sensíveis às peculiaridades de cada país e dos seus modelos de Welfare State costumam adotar posição contrária à instalação ou propagação dos fundos ${ }^{5}$.

No momento de indefinição aberto com a crise do governo Collor, os fundos de pensão brasileiros, além de serem considerados braços do vilipendiado esquema corporativista, estiveram na linha de fogo por terem se caracterizado como alvos da cobiça de integrantes do "esquema de corrupção" que teria se apoderado do governo central ${ }^{6}$. Em seguida, eles foram colocados no centro dos processos de privatização de empresas estatais em dois sentidos. No primeiro, na qualidade de "sócios capitalistas" dos grupos que se formaram para os leilões, situação em que se destacou, de um lado, seu papel na viabilização dos esquemas financeiros necessários para dar solvência aos lances e, de outro, o seu muito limitado poder de intervenção na conduta das empresas de que se tornaram co-proprietários. No outro sentido, eles apareceram novamente como problema, na medida em que as deficiências de capitalização que eles apresentavam se tornaram obstáculos ou simplesmente diminuíam o valor de venda das empresas que os patrocinavam. Podemos então falar em uma situação pouco favorável ao desenvolvimento dos fundos de pensão no período econômico que se abriu com Collor e prosseguiu nos governos FHC. Ainda assim, pudemos notar alguns prenúncios de mudança, a partir do momento em que diversos responsáveis governamentais passaram a lamentar-se por não terem dirigido o processo de privatização das empresas estatais por via de vendas pulverizadas de ações ${ }^{7}$, além da retomada de fôlego das discussões sobre câmaras setoriais e demais instrumentos de coordenação econômica e social, considerados corporativos até pouco tempo atrás e depreciados por causa dessa qualificação.

De fato, os fundos de pensão tiveram uma expressão curiosa no Brasil da última década. De um lado, foram indispensáveis na privatização das companhias estatais, um dos pilares da política econômica do gover- 
no federal pós-1994 ${ }^{2}$ De outro, no contexto da discussão sobre os rumos da previdência social brasileira, viram-se impugnados sob a alegação básica de constituírem instrumentos corporativos de preservação de privilégios vitalícios de grupos de trabalhadores já muito beneficiados pela estabilidade no emprego. Em um outro plano, mas também percebido como ameaça ao sistema, os bancos comerciais e empresas de seguros, após um longo período de aparente hibernação e/ou de tentativas erráticas de entrar no setor, lançaram-se no ramo da previdência complementar "aberta" (ao contrário do caráter "fechado" dos fundos de pensão tradicionais - fechados porque são disponíveis apenas para indivíduos que tenham algum vínculo especificado com a chamada "patrocinadora", a empresa que constituiu a fundação de previdência em questão), oferecendo agressivamente planos individuais para eventuais clientes e insinuandose como possíveis administradores "mais eficientes" dos fundos de pensão fechados em funcionamento ${ }^{9}$. Por outro lado, no mesmo período, os então dirigentes dos fundos ensaiaram a possibilidade de instituírem planos de previdência para o público externo, concorrendo assim com os bancos e companhias de seguro, mas essa pretensão foi rechaçada pelas autoridades econômicas governamentais ${ }^{10}$.

E para complicar ainda mais a configuração para os fundos de pensão, praticamente não foi lembrada sua possível contribuição no sentido de criar no Brasil o chamado "capitalismo popular", em que eles se constituiriam no mecanismo a partir do qual a classe média, coletivamente, iria ter acesso à propriedade das grandes empresas, ajudando a pulverizar seu controle, fazendo-as "públicas" no sentido norte-americano, e tornando nosso mundo empresarial, assim como nosso mercado financeiro, mais próximos dos ideais daquele país. Para os mais entusiasmados participantes do credo neoliberal, o capitalismo popular teria um efeito análogo ao da reforma agrária napoleônica: ao tornar a classe média e as franjas superiores da classe operária proprietárias de ações, esse processo mudaria inteiramente as orientações políticas daqueles estratos, tornando-os conservadores permanentes ${ }^{11}$.

Ainda que os fundos estivessem na defensiva durante todo o período, a situação é bastante ambígua. Afinal, vivemos sob a convenção de que o regime de capitalização, no qual cada indivíduo contribui para uma conta individual cujo montante deve ser aplicado hoje para ser sacado no futuro como dividendo gerado pelo seu pecúlio, é superior ao de repartição, no qual os trabalhadores (atualmente em atividade) pagam a aposentadoria daqueles inativos, tendo como premissa a promessa que serão eles a receber no tempo devido ${ }^{12}$. Ora, os fundos de pensão das empresas es- 
tatais iniciaram a capitalização no Brasil há pelo menos trinta anos, já sendo depositários de enormes magnitudes de poupança. Dessa maneira, deslegitimá-los é uma operação difícil, pois implica a necessidade de descaracterizá-los enquanto entidades verdadeiramente modernas ${ }^{13}$.

\section{O sistema}

Podemos falar em solidificação dos fundos quando a reiteração do seu funcionamento acabou consolidando em torno deles um grupo bem especificado de administradores, todos oriundos das equipes dirigentes das empresas estatais que os patrocinavam. Assim, os fundos tornaram-se uma espécie de exílio dourado, que aplacava as tensões das guerras de palácio típicas de grandes empresas estatais, em que a rede dominante do momento tem força suficiente para impor o seu mando na administração, mas não para demitir seus oponentes (Elias 1974). A exemplo de outros agrupamentos de profissionais ligados ao campo empresarial (Grün 1995), a consolidação desse conjunto, que irá autonomear-se "sistema" (dos fundos de pensão), passa fundamentalmente pela criação de uma entidade representativa, a Associação Brasileira de Previdência Privada (Abrapp), órgão que irá representá-los, educá-los e legitimá-los. Além dessas tarefas de representação, a Abrapp também passa a normalizar alguns de seus procedimentos. Diversos empreendimentos de vulto são viabilizados pela repartição de cotas entre os diversos fundos, pulverizando o risco dos negócios individuais e assim tornando-os possíveis. Em um registro mais genérico, o "sistema" procura construir a percepção da sua diferença específica. A idéia a ser fixada é a de que os fundos de pensão devem ter uma lógica de investimento distinta daquela observada pelo mercado financeiro: enquanto este fixa seu objetivo na lucratividade de curto prazo, implicitamente especulativa, os fundos devem ter um horizonte mais amplo - o longo prazo referente ao pagamento das aposentadorias e pensões, implicitamente em sintonia com políticas virtuosas de desenvolvimento econômico e social. E os corolários mais importantes dessa idéia são dois: 1) a gestão dos fundos de pensão é um ofício diferente das funções bancárias ou do mercado financeiro em geral; 2) os fundos de pensão devem ter seu funcionamento apoiado pelo governo federal, em especial mediante um tratamento fiscal privilegiado.

Entretanto, o funcionamento dos fundos no início do 1o governo FHC guardava peculiaridades que os tornavam vulneráveis à crítica dos seus detratores e à formação de coalizões que poderiam minar seu potencial 
de defesa. O grupo de dirigentes intitulado "sistema" desenvolveu estratégias de conquista e manutenção de espaços que os deixou a meio caminho entre os diversos atores coletivos da sociedade, tanto do lado dos atores econômicos "tradicionais", quanto em relação aos novos atores surgidos do renascimento do movimento sindical e dos movimentos sociais. Na medida em que os dirigentes dos fundos de pensão eram indicados pelas empresas patrocinadoras e tinham de trabalhar em coordenação com conselheiros eleitos pelos cotistas, eles acabavam desenvolvendo alguma interlocução com a representação dos funcionários e eventualmente se apoiavam nela para impor seus pontos de vista às direções das empresas. No ritual exigido para a nomeação dos dirigentes, eles deviam ser aprovados pelos comitês de administração (ou de curadores) das fundações, que costumavam ser integrados por representantes das empresas patrocinadoras e dos trabalhadores, com maior presença dos primeiros, já que normalmente a contribuição das empresas aos fundos é maior do que aquela proporcionada pelos empregados ${ }^{14}$.

Em mares menos perigosos, que correspondem aos períodos anteriores nos quais se formou o sistema, seu posicionamento lhes permitia grande margem de manobra em relação a possíveis injunções de quaisquer agentes externos ao grupo. Em uma situação de embate direto, ele ficava sem retaguarda. Assim, os fundos mantiveram durante muito tempo uma estratégia de "tudo ou nada" para seus cotistas — seus aderentes só poderiam gozar da aposentadoria se permanecessem empregados na empresa patrocinadora até a data daquele evento. Caso contrário, eles poderiam recuperar apenas a parcela que contribuíram diretamente, deixando a fração patronal das contribuições ao patrimônio dos fundos. Para as empresas patrocinadoras, essa era uma boa situação, na medida em que induzia à estabilização seus funcionários; para os fundos, esse modus operandi significava uma folga de capital que contornava eventuais problemas. Mas para os funcionários aderentes, a situação produzia uma limitação objetiva na liberdade de procurar novas inserções na vida econômica. Essa questão não era considerada relevante nas gerações passadas, mas tornou-se muito importante no "mundo do neoliberalismo", acentuando a diferença de destinos e de perspectivas entre as gerações que se sucedem nas empresas.

Outro ponto era o tratamento diferencial entre aderentes masculinos e femininos. Apesar de o montante de contribuição ser igual, os homens acabavam gozando de maiores direitos, já que suas parceiras matrimoniais poderiam desfrutar de pensões após o seu falecimento, o mesmo não acontecendo aos consortes das cotistas. Neste caso, também a situa- 
ção anacrônica produzia uma folga de caixa para os fundos e era mantida. Quanto aos eventuais parceiros de cotistas que praticavam vidas conjugais menos convencionais, nem mesmo os planos de saúde eram estendidos. É fácil notar que as propostas de transformação dos fundos em "verdadeiros fundos de pensão como nos Estados Unidos", que funcionassem de fato como fundos de capitalização, sem distinções que não as de magnitude de aplicação entre os diversos tipos de aderentes, tivessem boa acolhida entre jovens, que não vislumbravam uma carreira profissional inteiramente trilhada dentro da empresa em que estavam, entre as mulheres, que se sentiam prejudicadas pelas regras herdadas e mantidas de outras épocas, e também entre os membros das minorias sexuais. Além da questão conjuntural da incapacidade de manter aquela forma de funcionamento, essas peculiaridades dos fundos brasileiros também revelavam o seu caráter híbrido de entidades a meio-termo entre uma lógica familialista-patriarcal, em que pessoas diferentes têm direitos diferentes - e mais do que direitos, têm necessidades —, e a lógica bem mais individualista dos tempos que estavam se consolidando ${ }^{15}$.

\section{A deslegitimação}

Podemos sintetizar o formato das estratégias dos diversos atores que pretendiam ocupar o espaço conquistado pelo sistema como um ataque geral à pretensão da diferença. Este ataque se inicia no governo Collor, quando seus acólitos tentam se apropriar daquelas entidades, vistas como provedoras de fundos (recursos), para empreendimentos das mais diversas naturezas. No início do governo FHC, é a presença dos banqueiros, em especial os do novo ramo de bancos de investimentos, que se faz notar como "parceiros" dos fundos, especialmente nos processos de privatização que agitaram o período. Um episódio emblemático do gênero de parceria que os fundos foram obrigados a aceitar naquele momento foi o acordo entre os diversos fundos de pensão das estatais e o Banco Opportunity na criação da companhia de finalidade específica que participou no leilão da malha norte da Telebrás, depois rebatizada de Telemar.

Em paralelo às investidas do assim chamado "mercado", as lideranças sindicais também começaram a demonstrar interesse crescente nos fundos. Aqui, a tentativa era de fazer passar como natural a extensão do mandato de representação dos empregados das empresas da esfera sindical para aquela da previdência privada. O processo começa no setor dos bancários e vai se espraiando para as demais categorias: petroleiros, 
eletricitários, telefônicos e outros. O "sistema" ficou assim entre dois fogos. De um lado, a argumentação proveniente do "mercado" insistia que a formação técnica de seus prepostos os qualificaria melhor do que os membros do "sistema" para dirigir os fundos, negando a pretensão da diferença específica. Do outro, as lideranças sindicais anunciavam-se como os verdadeiros representantes dos empregados das empresas. E houve também diversas ocorrências de "fogo cruzado": no calor da luta para abrir espaços, vimos líderes sindicais apontando o caráter "amador" dos membros do "sistema", e representantes do mercado financeiro questionando a representatividade dos gerentes dos fundos. Assim, nenhuma surpresa, quando entrevistamos seus gestores no período 1997-1999 e deparamo-nos com posturas defensivas, que denotavam uma situação de extrema incerteza em relação ao seu futuro profissional. O perigo imediato eram as privatizações em marcha, que provavelmente iriam deslocá-los de suas posições no sistema. Além disso, tendo gozado até então de bastante autonomia, esses dirigentes estavam tendo a sua atuação monitorada de perto pela imprensa e muito cobrada pelas diversas agências governamentais. De um lado, a questão estratégica das privatizações, como apareceu no conteúdo das "fitas grampeadas" do BNDES16. Mas também a problemática dos débitos presumidos das empresas com os fundos, o chamado "passivo previdenciário", que poderia criar um impacto tão grande nas contas nacionais a ponto de inviabilizar as políticas de estabilização monetária ${ }^{17}$.

Havia aqui desconforto em duas frentes. Por um lado, a questão da "qualidade dos ativos" que o governo, por intermédio das diretorias das empresas sob seu controle, oferecia aos fundos para cobrir seus débitos. Os valores dos bens eram muito imprecisos e poderiam ter expressões muito diferentes. Como os efeitos da sua recepção "a menor" só seriam percebidos diretamente em um futuro estimado em dez anos ${ }^{18}$, a elasticidade poderia ser "absorvida" pelos atuais dirigentes, que assim deixariam o problema de pagar efetivamente no futuro o que hoje é chamado de déficit potencial (a diferença entre a soma de capital que hoje deveria estar frutificando para pagar as aposentadorias e pensões já contratadas, mas cujo recebimento pelos beneficiários só irá ocorrer no futuro, e o montante efetivamente já auferido pelo fundo de pensão) para seus sucessores da década seguinte.

Nessa estratégia de, segundo nossos entrevistados, "passar o mico para a frente", o sistema de previdência privada perdia sua autonomia, ficando em uma órbita muito baixa em relação aos problemas econômicos de curto prazo do governo federal e de alguns estaduais. Dessa ma- 
neira, deslegitimar as posições dos dirigentes dos fundos ante a opinião pública e mesmo diante de seus aderentes constituiu-se na maneira de conseguir a sua anuência para esses acertos de contas. E essa empreitada fica fácil no contexto produzido pela maré montante da toada neoliberal, que contesta a justeza das mais diversas instituições erigidas pelo setor público, quando seus integrantes se sentem eles mesmos parte ilegítima do esquema geral de dom e retribuição vigente hoje na sociedade. É oportuno lembrar que, em épocas anteriores, no espírito bismarckiano da necessidade de se criar uma burocracia autônoma em relação ao cotidiano do jogo do poder político, as aposentadorias diferenciadas e a estabilidade funcional eram consideradas compensações naturais para a devoção de bons profissionais ao setor público, que remunerava menos, oferecia carreiras mais lentas do que o setor privado, além de ensejar tentações de apropriação da coisa pública, que seriam evitadas justamente pela expectativa de futuro assegurado com as aposentadorias e pensões próximas aos salários da ativa.

Por outro lado, a imagem internacional dos fundos também causou prejuízo à "causa da previdência privada brasileira". Uma das características mais marcantes da evolução recente de seus êmulos norte-americanos foi, justamente, a sua inflexão em direção a políticas que privilegiam o horizonte do curto prazo. Elementos centrais da chamada "revolução dos acionistas", os fundos de pensão norte-americanos estiveram na linha de frente do movimento que procurou restaurar os direitos dos proprietários de ações em face do que era enxergado como sendo o excessivo predomínio dos interesses dos administradores profissionais nos destinos e nos resultados das public enterprises (aquelas que têm sua propriedade diluída em ações livremente negociadas nas bolsas de valores) norte-americanas. Para alcançar a mudança desejada, o principal instrumento foi a exigência militante de resultados financeiros de curto prazo, que era sistematicamente confrontada com a pretensão gerencial de estabelecimento de fundos de investimentos necessários para projetos de longo prazo $^{19}$. Estabeleceu-se, assim, uma contraposição entre administradores profissionais das empresas, voltados para o longo prazo, e investidores, principalmente os chamados institucionais, voltados para o curto prazo. Evidentemente, os argumentos utilizados pelos dois adversários nessa disputa têm características metafóricas marcantes, que transferem o debate de um possível campo da objetividade econômica para a esfera cultural, com todas as ambigüidades, imprecisões e também possibilidades que esta proporciona. Essa característica dos fundos de pensão, como um objeto cultural em disputa, sugere a sua abordagem a partir da 
idéia de construção de uma agenda, definindo as formas em torno das quais o debate sobre o assunto pode e deve tomar e que percorre essa análise.

\section{A agenda dos fundos}

Na tentativa de travar a discussão em torno de eixos que lhes sejam favoráveis, a peça de resistência do sistema consiste na afirmação, mil vezes repetida, mas nem por isso absorvida, de que os chamados investidores institucionais conceberiam e implementariam sua estratégia e portfólio de investimentos, a partir de um horizonte temporal muito mais longo do que os capitalistas individuais. Nesse sentido, eles seriam capazes de viabilizar tipos de empreendimentos necessários ao desenvolvimento do país que não seriam atrativos para os investidores tradicionais. Como os governos anunciam dificuldades cada vez maiores para assumir a função de investidores ou de fomento em geral, tal papel adquiriria uma importância estratégica ${ }^{20}$. Mas mesmo esse obstáculo foi contornado no período, quando diversos economistas afirmaram que as estratégias de investimentos dos fundos não discrepavam fundamentalmente daquelas praticadas pelos outros investidores, e mais que isso: ao especularem com massas enormes de dinheiro, eles agravariam ainda mais a instabilidade financeira que proclamam controlar ${ }^{21}$.

O setor reagiu fracamente, evidenciando, no mínimo, inabilidade em se fazer ouvir, talvez uma incapacidade para influenciar as pautas jornalísticas, na hipótese intermediária, e, no outro extremo, uma efetiva pouca independência em relação aos padrões de aplicação financeira vigentes no "mercado". Durante o debate travado em 1997, um então membro proeminente do sistema procurou defendê-lo, principalmente contra a possibilidade de taxação de seus rendimentos, na ocasião na agenda governamental, lembrando para isso os argumentos tradicionais sobre o papel dos fundos no fomento ao desenvolvimento. Ao mesmo tempo, ele tentou abrir uma outra frente, assinalando que a tentativa de "puxar o tapete" dos fundos beneficiaria os grandes bancos que procuram controlar as imensas quantias que o sistema de previdência privada gerencia. A julgar pela repercussão na imprensa, e pela falta de seguimento por parte dos membros do sistema, esse argumento antiplutocrata, tradicional e internacional no repertório da cultura econômica das classes médias não sensibilizou a agenda, caindo no vazio (embora ele costume ser acatado mesmo nos países anglo-saxões, que separam os 
fundos de pensão do sistema bancário) e ajudando-nos a comprovar as dificuldades do setor ${ }^{22}$.

No debate, Schwartz lembra algumas posturas típicas da posição atual dos fundos norte-americanos colocados no centro da "revolução dos acionistas" que agita aquele país, que os localiza como money managers dos mais agressivos. Já o nosso dirigente investe na postulação do papel distinto dos fundos, segundo a retórica aceita no setor, procurando realçar os compromissos dos fundos com o desenvolvimento do país ${ }^{23}$. Daí se seguiria, logicamente, uma preocupação dos gerentes dos fundos brasileiros com questões ligadas à pauta das correntes econômicas "desenvolvimentistas". Entretanto, ouvimos muito pouco nesse sentido. Ao contrário, quando entrevistamos os administradores em questão, um ponto dificilmente negligenciável seriam as repetidas manifestações de conhecimento da linguagem dos produtos e das ferramentas do mercado financeiro e dos seus meandros, como a querer provar diante do entrevistador capacidades que os próprios depoentes pareciam pôr em dúvida. Visivelmente, estávamos diante de um grupo que sentia o vento da deslegitimação. E assim, ao contrário do que poderíamos prever, no período considerado, nossos previdenciários, longe de se afirmarem como criadores e portadores de uma lógica de atuação diferenciada no mercado de capitais, como afinal predicam os próprios textos em que aprendem e ensinam seu ofício, eles faziam questão de se posicionar como dirigentes do mercado financeiro, tão capazes quanto qualquer congênere dos bancos privados.

Nesse quadro, cabe destacar a percepção do grupo sobre quem poderia constituir-se em seu aliado diante da invasão anunciada dos dirigentes procedentes dos bancos privados, chamados justamente de "profissionais" (em contraposição ao estado "amador" dos dirigentes do setor no momento das entrevistas) pela imprensa e pelos segmentos do governo interessados na questão. O grupo dividiu-se quanto ao assunto: para alguns, os dirigentes sindicais e políticos que tinham alguma tradição de representar os setores eram pura e simplesmente outro tipo de concorrente para suas posições; outros viam nesses agentes possíveis aliados, mas de maneira genérica ${ }^{24}$.

Quanto à possibilidade de impressionar a mídia e ter algum controle sobre a agenda de discussões do setor, a percepção geral era que se tratava, de antemão, de uma batalha perdida. Ainda assim, notamos o cuidado de alguns dirigentes em se cercar de assessores de imprensa com bom trânsito nas redações, com algum sucesso na publicização de eventos e realizações isolados, mas sem inverter o sentido geral do tom crítico adotado contra o setor. Talvez pela desconfiança em relação ao espaço 
sindical, uma possível mobilização dos cotistas dos fundos não parecia estar no horizonte de possibilidades de nossos entrevistados - com a possível exceção dos oriundos do setor bancário, em que a militância sindical se intensificou no período posterior ao de meu trabalho de campo e de onde saíram membros importantes do governo Lula, no qual, justamente, apareceu alguma ambigüidade. De qualquer maneira, um fato verificado naquele momento sugeriu que também o espaço sindical não enxergava especificidades no sistema: assistimos a uma mudança de pessoal dirigente na Funcesp, fundação que reúne os planos de pensão das companhias estatais de energia elétrica do Estado de São Paulo, por ocasião da privatização da maior parte de seus ativos. Nesse episódio, os então dirigentes do fundo de pensão foram considerados "amadores" pelas diversas instâncias de representação sindical (os sindicatos que representavam os eletricitários das diversas cidades, bases e centrais sindicais e também os conselhos de representantes de empregados criados no governo Franco Montoro, reunindo aderentes da CGT, da Força Sindical, da CUT e independentes) e substituídos por agentes recrutados no mercado financeiro, com backgrounds típicos desse espaço, que foram considerados, estes sim, "profissionais", com os diversos comunicados sindicais apoiando a mudança.

Outra questão que agitou o sistema previdenciário privado no período foi a tributação dos seus rendimentos, uma vez que, até aquele momento, eles eram isentos desse ônus. Entretanto, mais recentemente acabou prevalecendo a forte tendência governamental no sentido de taxar os seus resultados, tendo como argumento principal, justamente, o fato de os fundos não representarem nenhum tipo de agente que mereça consideração especial. Diante da perspectiva da reforma tributária que se avizinhava, o setor tenta fazer valer a sua excepcionalidade, com resultados que acabamos de conhecer mais recentemente ${ }^{25}$. Se considerarmos o Congresso Nacional e as altas esferas do Judiciário como arenas onde a legitimidade das formas institucionais é testada, acabamos de assistir a um teste decisivo, que pôs em causa a viabilidade do nosso embrião de capitalismo institucional ${ }^{26}$.

\section{Discussão}

A configuração encontrada pode ser explorada sociologicamente de diversas maneiras. Na análise de agenda a que me propus, ela permite esclarecer a questão do ator prototípico impensado que se move na arena 
do mundo econômico e sua relação com os destinos das classes médias brasileiras ${ }^{27}$.

A existência desse nosso ator pode ser considerada em três níveis. A primeira delas é na forma de artefato heurístico para uso do analista, como uma espécie de tipo ideal weberiano (Ringer 1997), mas que só é compreensível quando colocado em tensão com seu oposto sociológico (Lakoff 1996). O segundo nível é o de tipo ideal para o trabalho social e político de constituição de identidades. Diversos grupos de atores atuam na tentativa de produzir uma imagem das características tidas como corretas do perfil do investidor, e assim demolir as versões concorrentes. Nesse plano, estamos falando de um espaço social observável, objeto de batalhas cognitivas que fundamentam grande parte da luta política que transcorre na esfera pública (Bourdieu 1997). Por fim, temos o nível de influência dessas disputas no comportamento concreto dos agentes e entidades coletivas que se movem na sociedade. Aqui se materializam os resultados das batalhas cognitivas do segundo nível, mediante processos de aceite e de refutação das referências identitárias que são propostas (Boltanski 1982). Como nos lembram Bourdieu (2000) e Callon (1998), o chamado Homo œeconomicus não é nem uma simples criatura abstrata da teoria econômica, nem uma entidade que se pretende concreta, mas de existência controversa, mas um projeto robusto de profecia auto-realizadora sobre como devemos nos comportar em sociedade.

Podemos agora afirmar que, no caso que estamos estudando, as evidências mostram que vivemos uma tentativa de alterar o protótipo tradicional da figura do investidor e, conseqüentemente, do mercado financeiro e de suas funções, para fixar um novo modelo, mais próximo da visão prevalecente na chamada "economia financeira". Tradicionalmente, o mercado financeiro apresentava-se como a principal opção de poupança no longo prazo, através da qual uma família poderia constituir um patrimônio sólido e que cresceria pelo menos no mesmo ritmo que a economia em geral, mantendo seu valor relativo na escala de riquezas da nação e, portanto, o status do seu detentor. Na lógica da economia doméstica das famílias de classe média, esse tipo de aplicação era visto como um investimento seguro. Assim, complementarmente a algum investimento imobiliário, o mercado financeiro representava uma forma adequada de um pai de família previdente acumular capital e/ou diferir consumo para a eventualidade de ele "faltar" aos seus entes queridos. Já o mercado como um todo, correlativamente, funcionaria como um instrumento de captação de recursos dos indivíduos, que seriam aplicados em empresas com benefícios mútuos, uma vez que ali o capital levantado custaria menos 
do que na rede bancária, poderia ser reinvestido, pelo menos em parte, indefinidamente, e assim significaria uma obrigação a prazo bastante longo, suficiente para fazer frutificar os empreendimentos e apresentar a rentabilidade necessária para expandir a escala dos negócios e pagar confortavelmente os dividendos associados às aplicações do público. E a nação, na sua totalidade, ganharia com o crescimento e/ou aceleração da atividade econômica, que deveria gerar mais empregos, oportunidades de negócios e impostos. Chamemos essa versão de versão 1. E deixemos claro que a sua existência social é o resultado do trabalho de representação (de reapresentação, como Goody [1997] não se cansa de nos lembrar) de diversas gerações de operadores e líderes setoriais dos mercados de capitais e, mais recentemente, de dirigentes dos fundos de pensão interessados em consolidar a imagem de sua esfera de atuação como um espaço econômico legítimo, útil para a sociedade e seguro para os indivíduos, em oposição à imagem popular da bolsa de valores vista como um cassino.

Mais recentemente, a idéia de quem é o investidor mudou. E os ventos culturais e econômicos que sopram do Primeiro Mundo para o nosso lado trouxeram uma nova definição de mercado financeiro, correlata à mudança do tipo de ator que nele se move. O ator prototípico passou a ser uma figura mais próxima do ideal do jogador: alguém que se movimenta rapidamente em diversos campos, mudando freqüentemente seu portfólio ao sabor da percepção de novas oportunidades ou de buracos ou zonas de mau funcionamento no mercado (market failures) nos quais poderia exercer um papel de arbitragem. Diferente do tipo que o precedeu, ele louva o risco e não guarda nenhuma relação afetiva com seus investimentos, companhias ou ramos de atividade. Em vez da estabilidade e previsibilidade desejadas pelo antigo ator típico, aqui temos um indivíduo que procura e espera ganhos significativos em prazos curtos e que, portanto, está disposto a assumir riscos muito mais elevados. Seu pressuposto básico é que o dinheiro empregado nos investimentos, ao contrário da nossa versão 1, não é consumo diferido, o qual se perdido resultará em prejuízo irreparável, mas sim que o que ele perde hoje, ganhará amanhã. Portanto, estamos diante de alguém que muito provavelmente é jovem, marcado por características de gênero identificadas com o estereótipo da masculinidade 28 (frio, racional, corajoso, mas sem se deixar levar por emocionalismos), com poucas despesas fixas em relação ao montante que recebe normalmente, percebendo-se como em fase de ascensão na carreira e que enxerga nas aplicações mais uma maneira de enriquecer do que uma estratégia defensiva de controle dos riscos presentes nas diversas 
fases do ciclo de vida doméstico. Chamemos essa versão de versão 2. Trata-se de uma construção mais recente, resultado da simbiose desenvolvida entre os economistas que se dedicam à chamada "economia financeira" (Fligstein e Friedland 1995) e diversos "empreendedores morais" que transformaram a cultura do mercado financeiro anglo-saxão nos anos 80 e 90, conseguindo romper a associação popular entre risco e jogo, mediante a caução científica propiciada pelos economistas (Mackenzie e Millo no prelo). Como a maior parte das inovações institucionais, essa versão se instala como decorrência de uma intensa disputa entre gerações de agentes que atuam nos espaços concernentes, aqui os mercados financeiros, em um processo bem descrito etnograficamente por Thompson (1997).

No novo quadro, o mercado é visto como uma arena para "gente grande", local de encontro de indivíduos com as características do nosso "macho arrojado", no qual são realizadas operações de muito risco, sendo assim altamente desaconselhável para quem deseja simplesmente preparar-se para um futuro tranqüilo. Em lugar do antigo espaço benevolente em que os corretores tradicionais e confiáveis ensinavam e ajudavam os poupadores, traçando-lhes as vias por onde eles poderiam conseguir instalar-se sem sobressaltos, agora estamos diante de uma mesa de jogadores profissionais, em que todos conhecem as regras do jogo, submetem-se a elas e aceitam as marés de sorte ou de azar como riscos inerentes ao negócio. A própria idéia dos investimentos que faziam parte de um ciclo de vida doméstico, em que "havia o momento de semear para depois haver o momento de colher os frutos do trabalho", parece ter desaparecido, junto com qualquer concepção de tempo cíclico, conforme revela a análise dos outros objetos empíricos pesquisados anteriormente (Grün 1998; 1999).

A justificativa da versão 2 para a sociedade baseia-se justamente na noção acima exposta do market failure. Aqui, a palavra-chave é "arbitragem" : na medida em que existe um mercado para o controle acionário das empresas, o mercado financeiro, na sua visão agressiva, arbitraria seu verdadeiro valor, servindo para impor às sociedades anônimas um padrão de eficiência mais elevado, compatível com as expectativas dos acionistas. Os dirigentes das sociedades anônimas seriam punidos por ofertas de compra hostis ${ }^{29}$ que os desalojariam de seus cargos. Impondo essa disciplina através da "arbitragem", os mercados financeiros estariam prestando um serviço inestimável às sociedades, justamente porque obrigam as empresas e os indivíduos que delas fazem parte a dar o máximo de si para evitar os ataques especulativos. O resultado agregado da 
pressão sobre todas as empresas implicaria um aumento geral da produtividade do trabalho e, conseqüentemente, da satisfação dos seus clientes e da sociedade que contariam com bens e serviços de melhor qualidade e menor preço, além de fomentar o crescimento econômico de maneira mais ampla e consistente.

O que fazer quando não há esse mercado? É claro que a sua existência, representando o controle externo, ou pelo menos a sua ameaça, pairando sobre as cabeças dos dirigentes das empresas, é essencial para o funcionamento da "boa governança corporativa". Ainda que ele não exista na prática, é notável como se mantém como base dos modelos de análise e, cada vez mais, de ação - uma metáfora que procura adquirir existência literal. Assim, a saída preconizada é justamente trazê-lo à existência efetiva, o que no caso brasileiro está significando uma verdadeira militância dos financistas e também de alguns profissionais e líderes sindicais em prol da governança corporativa, cujos princípios aparecem publicamente como uma mudança importante na lei das sociedades anônimas, conferindo maior poder aos acionistas minoritários. Mas a resolução desse problema, ainda que considerada evidente pelos acadêmicos, financistas e jornalistas que intervêm na mídia, está longe de ser alcançada, por causa das resistências "surdas" que surgem dos mais diversos quadrantes ${ }^{30}$.

O ritmo febril de troca de papéis e de posições, os comportamentos erráticos dos agentes financeiros, a partir dos quais fortunas estavam sendo feitas e desfeitas em pouco tempo, afetando o destino de milhares de pessoas nas empresas e comunidades, em uma atmosfera parecida (mas não idêntica, dizem os bardos da nova era financeira) com uma mesa de jogo de azar, tudo isso se justificava por fazer os EUA reganharem as posições perdidas na "guerra econômica mundial". Aos outros países, onde o mercado financeiro funcionava de maneira diferente, nada mais restava do que seguir o exemplo e "impor sua disciplina" sobre as empresas indolentes, criando o mercado por controle acionário das empresas, antes inexistente ou inexpressivo (Dezalay 1994). Inclusive no Brasil ${ }^{31}$, essa visão ganhou destaque em discussão recente sobre os fundamentos do crescimento contínuo da economia norte-americana nos anos 90, que foi subseqüente a um período de extrema atividade do mercado financeiro em fusões, incorporações e aquisições, invertendo justamente uma tendência de "perda da hegemonia do capital norte-americano diante dos japoneses" 32 . 


\section{As vicissitudes das classes médias e a versão 1}

Nossas classes médias acreditaram muitas vezes na versão 1 e assim investiram parte de suas poupanças nas famosas blue chips, as ações das empresas mais confiáveis do país, em geral as prestadoras de serviços públicos, notadamente as companhias internacionais como a Light, a Telefônica e as estradas de ferro do Estado de São Paulo. A leitura de Saes (1986) sugere que, a partir do surto industrial induzido pela Primeira Guerra Mundial, esses investimentos tinham a qualidade de estarem relacionados mais ao desempenho da economia industrial urbana do que às fortunas oscilantes da agricultura cafeeira, servindo para as famílias tradicionais protegerem-se dos problemas da monocultura, explicando assim as facilidades que as companhias de serviços públicos encontravam para colocar seus papéis no mercado financeiro brasileiro, mesmo depois do encilhamento.

A ação de diversas crises e a transformação mais geral do entendimento do papel do mercado financeiro tornaram essa percepção relativa, e cada uma delas, a seu tempo, reativou a temida imagem do mercado financeiro como um cassino. Tivemos uma primeira grande adversidade com o encilhamento no fim do século passado (Taunay 1923 [1893]; Schulz 1996:95; Tannuri 1981), a gigantesca crise de 1929, aquela associada ao Plano de Ação Econômica do Governo (PAEG) de Roberto Campos, em 1964, e a da bolsa do início dos anos 70, além de diversas oscilações menos dramáticas (Levy 1977). As chamadas blue chips mudaram no decorrer da história. As primeiras foram as ações das prestadoras de serviços - as companhias ferroviárias, elétricas, as concessionárias de água - , em seguida, e principalmente depois de 1964, as grandes estatais Banco do Brasil e Petrobras ocuparam esse espaço, e mais recentemente pode estar havendo uma substituição desses papéis pelos das concessionárias recém-(re-)privatizadas. De alguma maneira, podemos associar o investimento neste tipo de empresa ao perfil do investidor da nossa versão 1 , já que ele representa um gênero de atividade econômica de demanda segura e com crescimento muito próximo ao da atividade econômica em geral.

Seriam os fundos de pensão os portadores atuais da nossa versão 1 ? Como vimos, na sua retórica, os fundos pretendem-se atores diferenciados, que organizam o futuro financeiro de seus aderentes. Para tanto, eles devem planejar seus investimentos para prazos mais longos, em função dos quais, eles, de alguma forma, adotam comportamentos que poderiam "domesticar o mercado", no sentido da noção de interesse geral associa- 
da à nossa versão 1, exigindo de seus possíveis parceiros nos negócios condutas e atitudes "mais responsáveis", tendo em vista o horizonte de previsibilidade de quem tem contas a prestar para o resto das vidas dos pensionistas. Dado o seu grande e crescente peso, relativo aos demais agentes atuando nos mercados financeiros e de valores em geral, as formas de configurar negócios que são próprias dos fundos de pensão tornar-se-iam também cada vez mais disseminadas, consagrando a versão 1.

Mas o comportamento observado dos fundos, nos dois anos da pesquisa, foi bastante ambivalente. De um lado, seus gerentes tentavam escorar-se na perspectiva da nossa versão 1, afirmando a hipótese acima exposta. Essa atitude aparecia em diversas ocasiões públicas, em que nossos entrevistados prestavam contas de seus atos para os aderentes. Entretanto, diante da "ofensiva neoliberal", percebemos seus dirigentes tentando se posicionar como atores legítimos da nova era - "homens do mercado", com características semelhantes aos financistas das outras organizações.

Podem eles operar na versão 2 sem se descaracterizar? A versão 2 costuma ser estruturada em torno de uma análise do tipo Principal/Agente - no jargão, a P/A (Fama 1980). Nela, o papel dos fundos, enquanto Agentes, seria o de maximizar os ganhos de seus cotistas, os Principais, e estes disporiam para isso de instrumentos de benchmarking - a comparação do desempenho de seu fundo com as melhores performances atingidas no mercado (Fligstein e Friedland 1995). A linha de resistência retórica dos fundos insiste na idéia de que eles devem ser gestores prudentes de uma poupança sagrada, a qual, se dilapidada, dificilmente poderá ser reposta, o que afastaria suas rentabilidades dos máximos de mercado, que seriam o produto de posturas excessivamente arriscadas. Durante a maior parte do governo FHC, a Secretaria de Previdência Complementar, órgão do Ministério da Previdência encarregado de fiscalizar os fundos, tentou conduzir a agenda para um entendimento mais próximo do espírito da P/A, tentando conotar que resultados muito diferentes dos benchmarkings (denominação indígena para designar um nível ótimo de atuação em uma determinada atividade e que deve ser buscado por todos os agentes que realizam tarefas semelhantes) indicariam na verdade condutas de depositários infiéis ${ }^{33}$.

E pelo que estamos vendo, não saímos do nosso mar de metáforas. É possível que esse entendimento seja correto em alguns ou mesmo na maioria dos casos, com aplicações mal feitas ou simplesmente realizadas para auferir alguma vantagem pessoal ao indivíduo aplicador, que então se caracterizaria efetivamente como depositário infiel. Mas os resultados 
menos expressivos das aplicações dos fundos também poderiam denotar uma genuína preocupação com a solidez do patrimônio de seus aderentes $^{34}$.

Daí o duplo constrangimento: diante dos seus representados, o sistema mostra-se como fiador de um futuro seguro, posicionamento que deveria traduzir-se em políticas conservadoras de aplicação de recursos; perante os seus contendores do mercado financeiro, ele tenta aparecer como fazendo parte da "pátria financeira", conformando-se ao seu figurino. Estamos diante de uma ambivalência dificilmente administrável no médio prazo. Seguindo Boltanski e Thévenot (1991), poderíamos pensar em figuras de compromisso entre as duas ordens de argumentação que se constituiriam em um espaço de convívio, ainda que tenso e instável. Não as encontramos empiricamente, o que não quer dizer que elas não existam e possam ser descobertas ou engendradas no futuro. Já se seguirmos Elias (1974), o problema ganha outra interpretação: a hesitação e mesmo a aparente paralisia dos membros do sistema em face do ataque que sofriam denotaria a incapacidade de reforma do mesmo, já que todos os seus beneficiários estariam umbilicalmente ligados por uma rede de privilégios, e "cortar na carne" seria uma estratégia que desestabilizaria todo o conjunto. E esta maneira de ver o contencioso confirmaria a hipótese de que os fundos são parte do "entulho corporativista".

Mas, passada a fase de encantamento com as receitas econômicas "neoliberais", os ventos mudaram os seus rumos. A questão do desemprego instalou-se como problema central da sociedade brasileira do fim do milênio, ainda que o edifício ideológico que sustenta a nossa versão 2 faça tudo para desalojá-lo. Também, pudera, nosso receituário neoliberal não tem remédio específico para essa doença - a não ser, "matar o doente" - insistindo que a desregulamentação absoluta do "mercado" de trabalho traria a verdade dos preços para esse espaço, que só assim funcionaria como um verdadeiro mercado, obrigando os indivíduos vendedores de trabalho a baixarem seus preços até que haja demanda para seus préstimos e, assim, mostrando que o desemprego não é o verdadeiro problema. Nem a nossa nem nenhuma outra sociedade se deixou levar a esse ponto, a barbárie capitalista enunciada por Karl Polanyi. Mas essa "falta de ousadia" será sempre lembrada pelos economistas mais extremados como a verdadeira causa do desemprego ${ }^{35}$.

Em torno da mudança de agenda, políticas de concertação voltam a ter droit de cité, e com ela a versão 1 e os atores coletivos estigmatizados no período anterior. As políticas de desenvolvimento regional, que antes eram consideradas "antinaturais", voltaram com força ao debate público. 
Mais do que simples sócios provedores de capital sem direito a voz para os empreendimentos, estamos agora diante da possibilidade de ampliação da margem de atuação dos fundos, que começou a ser efetivamente percebida a partir do ano 2000. Mas utilizá-la não é simplesmente aproveitar uma "oportunidade tática"; trata-se antes de uma opção estratégica que implica uma flexão identitária no sentido de os fundos posicionarem-se mais próximos da constelação da representação política sindical de interesses. Isto significaria um movimento ousado, pouco provável se pensarmos a partir dos titubeios e da identidade partida dos seus dirigentes identificados nas entrevistas. Entretanto, as possibilidades que se abriram com a vitória de Lula nas eleições presidenciais de 2002 tornaram essa hipótese muito mais provável.

As mudanças no momento político-cultural, ao lado do simples instinto de sobrevivência dos atores, trouxeram surpresas. Nela mesma, a possibilidade de flexão identitária coloca um interessante problema sociológico sobre "habitus" e "técnicas de trabalho sobre si próprio" na sociedade atual ${ }^{36}$. Livros de grande impacto editorial escritos por sociólogos como Castells (1996) têm insistido no caráter inédito dos tempos atuais, quando estaríamos obrigados a uma permanente reconstrução identitária para continuarmos viáveis em um mundo em constante mutação. Provavelmente, como grande parte das obras que obtêm sucesso midiático, esses materiais exageram as novidades em detrimento das permanências. Mas, muito além da sua acuidade científica, talvez fosse interessante considerarmos que estamos diante de "manuais de sobrevivência na selva", que bem poderiam estar como destaque erudito nas prateleiras, cada vez mais numerosas, e não por acaso, dos livros de auto-ajuda, que procuram ensinar técnicas de adaptação do indivíduo a situações de risco ${ }^{37}$.

\section{Uma nova ordem?}

Uma caracterização, e uma possibilidade lógica de entendimento dos tempos atuais, fala da constituição de uma ordem de justificação oriunda do "mundo conexionista". Entre outros autores, esta figura foi proposta por Boltanski e Chiapello (1999) para dar conta da particularidade dos tempos em que estamos vivendo. Por esse princípio, poderíamos pensar em uma construção de legitimidade baseada no posicionamento dos fundos de pensão como "nós centrais de redes", que uniriam o universo dos trabalhadores aderentes a eles com o "capital-indústria" dos empreendedores descapitalizados em relação ao tamanho de seus projetos ${ }^{38}$. Se- 
guindo os analistas/proponentes dessa nova maneira de justificação, ela se constitui na essência mesma do capitalismo atual. Ela se distingue da ordem meramente comercial atualizada na versão financeira, a nossa versão 2, na qual muitos analistas (Orléan 1999:197) crêem encontrar a particularidade econômica dos tempos atuais, pela ênfase na solidificação de contatos em vez da preservação das condições de concorrência perfeita que dão legitimidade à outra visão. Prosseguindo por essa via, poderíamos pensar em um novo virtuosismo dos fundos, através do estímulo sistemático à busca de novas oportunidades - novos projetos, novas conexões - para seus aderentes ou para a sociedade ampliada. Estaríamos assim assistindo ao nascimento de uma "versão 3", que seria mais estável do que uma eventual figura de compromisso entre as versões 1 e 2 .

Retoricamente, essa alternativa é consistente, tanto em termos lógicos quanto no que se refere à sua filiação ao universo do "moderno". Ela fornece uma base mais geral ao novo desenvolvimentismo, que tem na política de distritos industriais a sua face pública mais visível e na idéia anglo-saxã de "capital social" a sua face teórica (Putnam et alii, 1993). Pudemos enxergar tentativas de movimentos, nesse sentido, por parte dos dirigentes dos fundos, quando eles procuraram oferecer alternativas a seus filiados e justificar-se diante das opiniões. Assim sendo, durante o período considerado, os dirigentes dos fundos de pensão propuseram constituir-se em provedores de "capital de risco" para empresas de alta tecnologia e para financiar o estabelecimento de franquias, além de anunciarem a participação em diversas montagens de empreendimentos de impacto em economias regionais, como grandes projetos turísticos e shopping centers.

O papel dos fundos foi bem aceito no período para os empreendimentos imobiliários, aprofundando e tentando renomear uma prática mais antiga. Mas a sua possível participação em esquemas de capital de risco, que os aproximaria da atual "via real" desenhada em torno da epopéia capitalista do Silicon Valley - que fornece a maior parte dos "bons" exemplos de conexionismo — , foi rechaçada pelas autoridades governamentais nos anos em que fomos governados por FHC. Naquela época, esse espaço foi reservado especialmente aos bancos de investimentos, tidos como o núcleo central do desenho de capitalismo concebido no período. Já no momento atual, em que figuras importantes do grupo de petistas que se interessavam pelas questões de previdência privada, como Luís Gushiken e Ricardo Berzoini, fazem parte do grupo mais próximo de Lula, torna-se fascinante observar as novas localizações dos fundos na arena econômica. 


\section{Conclusão}

A guerra cultural construiu e reconstruiu os fundos de pensão brasileiros em vários sentidos. Primeiro, produzindo os contornos do mercado econômico no qual eles se desenvolvem. Em seguida, definindo os critérios de legitimidade para os atores que poderiam ser seus dirigentes e para os direitos de seus aderentes. Propus uma explicação para a dinâmica do contencioso baseada na disputa entre três protótipos de agentes e de funcionamento do mercado financeiro, gerando as três versões que discuti. Em uma boa ilustração da dinâmica do "mapa cultural" proposto por Douglas (1996), a versão 2 prevaleceu, mas não integralmente. Ainda que os economistas mainstreamers que se ungiram em intelectuais orgânicos dos tempos em que passamos tudo fizessem para que a sua vitória fosse total, o mundo real é mais complexo do que a formação da agenda do jet set midiático e empresarial.

A grande arma do registro de "modernas" para as práticas identificadas com a versão 2 e de "arcaicas" para aquelas que impediam o seu predomínio foi usada à exaustão, mas apesar disso o jogo não acabou. No período FHC, o espaço para a atualização e a expansão dos fundos foi consideravelmente restringido pela ação de diversas agências do governo federal, apoiadas pela crítica ao corporativismo. Mas, mesmo assim, na arena ampliada que fornece legitimidade para as construções institucionais, pudemos notar que, apesar de toda a pressão, as raízes para o revigoramento da versão 1 ou para o desenvolvimento de uma possível versão 3 não foram destruídas. Dessa maneira, usando a velha e sempre atual fórmula de Marx, a lógica das coisas supera as coisas da lógica: os dados coligidos conduzem-nos a evitar a tentação de reduzir o espaço público a uma cinética produzida pelos argumentos e pela mnemônica deles derivada. De qualquer maneira, é importante ter claro que esse gênero de análise nos fornece boas indicações sobre as condições de possibilidade dos discursos e sobre a previsibilidade dos seus desdobramentos. Essa discussão nos coloca diante do estatuto das versões: são elas simples artefatos heurísticos que nos ajudam a modelar a análise ou devemos pensar nelas como as bases para a produção da agenda "metapolítica" que irá balizar a guerra cultural (Lakoff 1996)? Se, com Bourdieu (1997), pensarmos nas versões como princípios de divisão do mundo social e, conseqüentemente, como princípios práticos, interiorizados, de apreensão da realidade, a segunda hipótese ganha corpo - e a análise que proponho, relevância.

Voltando aos dados: para integrar a cinética à dinâmica social é interessante dirigir a atenção aos fatores que impedem a conclusão lógica 
da versão 2 na arena pública. O universo trabalhista resistiu à ofensiva que se abateu sobre ele e, diferentemente de outras latitudes, a questão do desemprego não foi renomeada e recategorizada como um problema de assistência social (Paugam 1994; Castel 1995). Da mesma maneira, o "tradicional" universo empresarial brasileiro não se deixou embalar totalmente pelo canto de sereia do neoliberalismo e, de maneira ainda a ser esclarecida, resistiu à transformação profunda de sua estrutura legal que esteve em gestação no período, com as propostas iniciais da nova Lei das Sociedades Anônimas. Assim, ao que parece, tanto o capital quanto o trabalho organizado nas suas federações parecem ter saído do ataque dos últimos anos menos mal do que poderia ser previsto pelos profetas do apocalipse. E tudo isso em um espaço simbólico aparentemente dominado pela constelação ideológica que sustenta a nossa versão 2. Daí, só podemos concluir que a década neoliberal não o foi tanto assim...

Creio que é nesse registro que podemos tentar especificar o significado da versão 3 que foi aventada pela análise. Primeiro e mais importante, nenhuma certeza teórica pode evitar a necessidade de séries de monografias sobre as diversas arenas sociais nas quais os princípios de organização social se digladiam. Só em seguida podemos sugerir a tentação de concordar com a idéia de que provavelmente ela encobre uma reestruturação retórica do princípio da hierarquia, momentaneamente indizível, mas ainda assim ancorando largos espaços da nossa sociabilidade. Nesse sentido, a continuidade da questão no governo Lula que se inicia apresenta uma oportunidade imperdível.

Roberto Grün é doutor em Ciências Humanas pela Unicamp e professor do Departamento de Engenharia de Produção da Universidade Federal de São Carlos; é autor de A revolução dos gerentes brasileiros (1995) e Negócios \& famílias: armênios em São Paulo (1994). E-Mail: grun@power.ufscar.br. 


\section{Notas}

* Este texto foi escrito a partir de dados extraídos de pesquisas financiadas pela Fundação de Amparo à Pesquisa do Estado de São Paulo (FAPESP) e pelo Conselho Nacional de Desenvolvimento Científico e Tecnológico (CNPq), a quem agradeço o apoio prestado.

1 Tratei dessa questão no nível microssociológico em Grün (1986).

2 Não se pode deixar de registrar a advertência de Hacking quanto ao uso irrefletido da metáfora da "guerra" para descrever disputas intelectuais e suas possíveis derivações para o convívio. Como quer o autor: "Metáforas influenciam a mente de várias maneiras, e algumas pouco perceptíveis. A desenvoltura em descrever desentendimentos agudos em termos de metáforas de guerra faz a existência mesma de guerras de verdade parecer mais natural, mais inevitável, mais parte da condição humana. Ela também produz uma insensibilidade em relação à idéia mesma de guerra, tornando-nos menos conscientes do quão totalmente ruins são as guerras reais" (1999:viii). Entretanto, ainda que sensibilizado pelo alerta, acredito que o termo "guerra" tem a virtude de mostrar a relevância da disputa e de suas conseqüências para vitoriosos e derrotados.

3 Trata-se da série de reportagens veiculada pelo jornal O Estado de S. Paulo a partir de agosto de 1976 que tratavam dos abusos cometidos pelas administrações das empresas estatais em benefício de seus administradores e funcionários. Rapidamente, o termo "mordomia" entrou para o vocabulário nacional e ganhou a esfera pública como sinônimo da situação que foi caracterizada como um profundo desvio de conduta, sintoma irrefutável da falência da possibilidade de uma boa gestão pública. A simples utilização da expressão passou a deflagrar as seqüências mnemônicas que "satanizavam" o setor público. Uma consulta aos dicionários brasileiros de língua portuguesa de antes e depois daquele momento é bastante útil para averiguar a extensão do fenômeno da impugnação.

4 Detalho essa cronologia em Grun (1999).

5 Ver a discussão sobre diversos aspectos das tentativas de transplante do modelo anglo-saxão de fundos de pensão para a Europa Ocidental em Economy and Society, vol. 29, no 1, de fevereiro de 2000. De maneira geral, há uma grande desconfiança quanto ao possível papel dessas instituições, já que se imagina que a sua adoção em larga escala traria para a Europa a maneira norte-americana de condução da vida empresarial — a "governança corporativa" — , que implicaria o privilégio absoluto dos interesses dos acionistas das empresas em detrimento daqueles normalmente atribuídos aos seus trabalhadores e às comunidades onde as empresas estão localizadas. E, conseqüentemente, a adoção dos fundos como mecanismo privilegiado de formação de poupanças poderia induzir a transformações indesejadas nos mercados de trabalho europeus, tornando-os mais próximos do 
norte-americano. Até o momento em que a redação deste artigo se encerrou, esse aspecto dos fundos de pensão ainda (?) não tinha sido enfatizado pelo movimento sindical brasileiro. Mas, para o bem e para o mal, o mundo está cada vez mais "globalizado". De qualquer maneira, é útil lembrar que no Brasil, diferentemente da Europa Ocidental, as entidades chamadas de "fundos de pensão" já têm peso expressivo na economia e, portanto, a nossa guerra cultural trava-se em torno da sua (re)definição.

6 Ver, p. ex., a coluna de Luís Nassif na Folha de S. Paulo, de 28/1/94: "O enquadramento dos fundos", e, no mesmo jornal, edição de 24/7/94, o texto de Antonio Kandir: "Corporativismo versus cidadania". Os títulos das matérias falam diretamente...

7 Ver, p. ex., Folha de S. Paulo, 18/11/99, em Painel Econômico, "Privatização pulverizada": "Causa polêmica a proposta do ministro Martus Tavares de mudar regras para pulverizar a venda de ações de estatais no ano 2000. 0 governo não bancou a idéia antes também por temer o efeito de uma queda nas bolsas, na poupança de microinvestidores - e na popularidade de FHC".

8 E do projeto anunciado de transformação do Brasil, em que o governo deveria concentrar-se nas suas zonas de atuação típicas, como prover a população de boas condições de educação e saúde, deixando a atividade produtiva direta nas mãos melhor preparadas dos particulares.

9 Ver, p. ex., o despacho da Agência Estado, 13/11/99 — 20h40: "Previdência privada ganha mercado".

${ }^{10}$ Com a vitória presidencial de Lula a questão começou a ganhar outro rumo.

11 Verificamos menções isoladas a esse possível papel nas falas pós-defenestração de ex-dirigentes governamentais, como Luiz Carlos Mendonça de Barros. Da mesma maneira, mas em sentido contrário, encontramos "revelações de intenções não realizadas" nas manifestações públicas de Gustavo Franco também depois de sua saída do governo. Esses fenômenos sugerem que, na lógica de "campo" da sociologia de Bourdieu, as indiscrições e saliências em geral veiculadas pelos ex-membros das altas esferas do governo, ainda que problemáticas como descrições factuais, podem ser consideradas reveladores fortes dos valores em jogo naquele espaço de poder. Em setembro de 2000, o mainstream das autoridades econômicas federais ensaia uma entrada no assunto, ligando-o à temática da "governança corporativa" (despacho da Agência Estado, 7/9/00 - 17h21: "Fraga: governo incentivará fundos de pensão"). 
12 A crítica a essa "sabedoria convencional" insiste que as gerações posteriores pagarão de qualquer maneira a aposentadoria das presentes, seja sob a forma generosa da repartição, seja sob a forma mesquinha de uma divisão mais adversa dos frutos da atividade econômica do futuro, pressionando a relação salário/lucro, já que a capitalização é produzida através da remuneração dos capitais investidos nas diversas atividades contempladas pelos fundos de pensão. E, por trás dessa discussão, aparece a certeza dos partidários da capitalização de que esta é melhor também porque aqueles que a controlam são menos ligados aos governos e à política e, por isso, gerem melhor os capitais que lhes são confiados. Já os partidários da repartição apontam as diversas situações, nas quais gestores de fundos privados são caracterizados como "depositários infiéis", para fazer crer que não há diferenças intrínsecas entre as capacidades de gestão dos dois tipos de regime. Uma defesa dessa contracorrente encontra-se em Nikonoff (1999).

${ }^{13} \mathrm{E}$, para controlar o jogo de metáforas, é bom lembrar que a "modernidade" da capitalização remonta pelo menos a Lavoisier e a Condorcet (ver Bourdelais 1997).

14 Quando encerrei a redação deste artigo, travava-se uma disputa na "Previ", o maior fundo de pensão brasileiro, destinado aos funcionários do Banco do Brasil, tendo justamente por contencioso esses temas da representação e das contribuições. Ver "Previ sem comando e à beira de uma guerra judicial" no site www. Estadao.com.br, 12/5/02. No governo Lula, com a nomeação de Sergio Rosa, um grupo de sindicalistas ligados à CUT passa a comandar a instituição, ainda que de maneira não absoluta. Seria assim muito interessante uma pesquisa mais focada sobre a evolução do interesse dos diferentes tipos de sindicato no que diz respeito aos fundos de pensão.

${ }^{15} \mathrm{E}$, ademais, perduraram no período, para a maior parte das fundações de previdência privada, regras de contribuição e de benefícios muito favoráveis aos funcionários mais antigos das empresas patrocinadoras, em particular no que diz respeito à integralização dos pecúlios para garantir a aposentadoria em boas condições dos altos funcionários que se aposentaram em massa na mesma época em que foi deslanchado o processo de privatização de grande parte das empresas estatais patrocinadoras. E a análise dessa concomitância - além de ser um excelente exercício de sociologia das gerações — provavelmente dirá muito sobre a aparente falta de reação ao processo de privatização.

16 Ver, p. ex., "Mendonça diz que só acompanhou grupos", Folha de S. Paulo, $11 / 12 / 98$.

${ }^{17} \mathrm{O}$ "passivo previdenciário", evidentemente, não foi criado somente nos últimos anos. A maior sensibilidade a eles deve vir, provavelmente, da política de privatizações, que inclui a necessidade de contabilizá-lo de acordo com os princípios contábeis geralmente aceitos em escala internacional. Trato do problema adiante. 
18 Isto porque, dadas as peculiaridades demográficas dos grupos de funcionários, a partir desse intervalo uma quantidade bem maior de cotistas passaria à condição de aposentados, deixando de contribuir e passando a receber dos fundos. Só naquele momento é que iria efetivamente faltar recursos para pagar as aposentadorias contratadas.

${ }^{19}$ Notemos que os maiores players daquele setor também são fundos de funcionários do setor público, como o "Calpers" dos funcionários do Estado da Califórnia e o seu êmulo do Estado de New York. Detalhes da configuração norteamericana podem ser encontrados em Useem (1993).

20 Mas, como veremos no decorrer do texto, a posição dos fundos no campo do poder brasileiro irá mudar na quadra petista. Ver, p. ex., Valor Econômico, 29/5/03: "Lula defende expansão da poupança pela via dos fundos de pensão", em que o atual presidente da República defende um novo posicionamento dos fundos de pensão.

${ }^{21}$ Ver "Fundos de pensão podem agravar instabilidade", assinado pelo colunista Gilson Schwartz, em Folha de S. Paulo, 9/11/97, que dá tintas ao argumento. Notemos que o economista, responsável por uma coluna permanente que manteve posições críticas em relação à maior parte da ação econômica do governo FHC, participa da toada "antifundos", denotando o estreitamento do espaço de legitimidade em que o sistema podia trafegar.

22 A questão do plutocratismo é explorada sistematicamente por P. Birnbaum (1979). Aterrissando no nosso tema, ver "Os fundos de pensão e a imunidade fiscal", assinado por Henrique Waksman, então presidente da Fundação Cesp, em Folha de S. Paulo, 9/11/97. Também pudemos notar algum recurso à retórica da luta contra a plutocracia em várias críticas feitas ao processo de privatização na segunda metade dos anos 90, mais em sites e na imprensa sindical e nacionalista do que na grande imprensa ou no debate parlamentar, provavelmente denotando a marginalidade do argumento no debate público brasileiro. Abordo alguns aspectos da questão da plutocracia no Brasil recente em Grün (2003).

23 O período posterior, provavelmente devido ao abalo produzido pelo caso Enron e seguintes, assistiu também a uma mudança no comportamento dos fundos norte-americanos, relativizando seu caráter "curto-prazista" e aproximandoos da nova orientação que seus análogos brasileiros passam a ter na quadra petista. Ver, p. ex., The New York Times, 13/10/02: “Calpers wears a Party, or Union, label", em que são descritas várias mudanças no comportamento do maior fundo de pensão norte-americano rumo a preocupações sociais e ambientais.

${ }^{24}$ A evolução do processo mostrou as centrais sindicais interessadas na previdência privada e tentando mais sistematicamente ocupar espaços no sistema e sendo atacadas por isso. Ver, p. ex., entrevista com Eduardo Jorge Caldas Pereira, 19/5/02, coluna Elio Gaspari, difundida por O Globo e Folha de S. Paulo. 
${ }^{25}$ Para os especialistas tributários existe o problema de uma possível bitributação desses rendimentos, que seriam taxados quando da percepção dos salários que contribuem para os fundos e, em seguida, pelos rendimentos dos fundos. Ver, entre outros, O Globo, "STF ameaça isenção dos fundos", 9/11/01, que descreve a tramitação jurídica que acabou prevalecendo. Para uma idéia da magnitude das cifras que estavam em jogo, ver Valor Econômico, 18/2/02 :"Contribuição recorde dos fundos".

${ }^{26}$ Sobre o conceito de "capitalismo institucionalizado", ver Useem (1984).

${ }^{27}$ Uso a expressão "ator prototípico" inspirado nas análises cognitivistas que assinalam a existência de uma forma recorrente de produção e extensão de categorias sociais de entendimento, em que se forma um conceito central típico e seu significado estende-se até os casos-limite que fazem esbarrar o protótipo em outras categorias. O caso mais conhecido é a formação do conceito de "cachorro": as crianças interiorizam um exemplo típico da imagem do animal em sua região, normalmente, o vira-latas local. Em torno dele vão sendo enquadradas as diversas raças, até chegarmos a exemplos de classificação duvidosa, como o cão pequinês, considerado espontaneamente como "gato" pelas crianças em idade pré-escolar e que, posteriormente, já na escola, "corrigem" essa classificação quando aprendem a categorização erudita da espécie biológica intitulada "cachorro". A introdução desse tipo de análise na sociologia se inspira na leitura dos estudos cognitivistas de E. Rosch. Boltanski (1982) faz uma digressão a respeito. Hirschfeld e Gelman (1994) atualizam as preocupações de Rosch em uma abordagem mais sociológica. Ver, em especial, Hirschfeld (1994).

${ }^{28}$ Para a antropologia dessa entidade, ver Rieder (1990) e Douglas e Ney (1998).

${ }^{29}$ Nessas operações, agentes do mercado financeiro descobrem que alguma grande empresa está sendo mal-administrada - isto querendo dizer que ela apresenta menor lucratividade do que poderia — e "montam" uma operação de compra de ações da empresa, para em seguida propor aos outros acionistas que exijam a convocação de uma assembléia cuja pauta seria a destituição dos diretores da empresa, justamente porque eles não são capazes de produzir a lucratividade possível e desejada. Uma descrição romanesca do processo encontra-se no filme Com o dinheiro dos outros, estrelado por Danny DeVitto, disponível no mercado brasileiro de locação de filmes em vídeo e em DVD (Other people's money, 1991, dirigido por N. Jewison). Para uma visão erudita, ver Useem (1996).

30 Ver despacho da Agência Estado, 20/9/00 - 20h51: "Kandir admite alterações na lei das S.As. “, em que o relator da tentativa de alteração da lei das S.As. no Congresso Nacional, um dos deputados mais próximos do espírito da equipe econômica de FHC, admite esbarrar em dificuldades talvez incontornáveis para chegar ao resultado "lógico", esperado pelos nossos profetas do "bom capitalismo". E a análise dessas dificuldades acaba se tornando uma excelente pista empírica para acompanharmos as vicissitudes da evolução do capitalismo brasileiro. Analiso esse percurso em Grün (2003). 
31 Ver despacho da Agência Estado, 7/9/00 - 17h21: "Fraga: governo incentivará fundos de pensão".

32 Ver o sugestivo artigo: "Ready to take on the world", The Economist, 15/1/94, pp. 65-66.

33 Ver o site http://www.mpas.gov.br/08.htm (20/12/00) e o despacho da Agência Estado, 4/12/00 - 10h21: “Trabalhador poderá fiscalizar fundo de pensão": "Os trabalhadores associados a fundos de pensão poderão fiscalizar a aplicação dos recursos de suas aposentadorias no site da Previdência Social. A intenção é evitar o mau uso dos recursos dos associados pelos planos de previdência privada". É interessante notar que a secretária de Previdência Complementar Solange Paiva, que insistiu na adoção extremada desse princípio, acabou sendo demitida por criar muitos atritos com os fundos, denotando os limites da postura de ataque agressivo às suas práticas habituais. Ver despacho da Agência Estado, 26/6/01 - 12h28: "Ministro anuncia demissão de secretária".

${ }^{34}$ Nos últimos vinte anos, desenvolveu-se enormemente a chamada "contabilidade crítica", principalmente na Inglaterra e, em menor escala, nos Estados Unidos. Um dos pontos mais abordados por essa corrente é justamente a imprecisão e o caráter contingencial das medidas contábeis e financeiras de valor das empresas. Um apanhado geral dessa abordagem pode ser encontrado em Hopwood e Miller (1994).

35 Sobre essa lógica metafórica das teorias econômicas derivadas do marginalismo, ver Douglas e Ney (1998:35). Sobre a "insensibilização social" produzida pela teoria econômica, ver Thompson (1998:218).

36 Ver Menger (1997), onde o autor, depois de examinar as flexões profissionais e identitárias a que os atores são obrigados enquanto trabalhadores sem emprego fixo e verificar que as oportunidades de trabalho são dependentes do constante re-trabalhar de suas potencialidades e suas redes de relações, pergunta-se justamente se os constrangimentos identificados na vida de seus atores profissionais não prefiguram as formas básicas da sociabilidade contemporânea mais geral.

37 Ver, entre outras, Revista Veja, no 711, 1/8/01: “Pague e seja feliz: enfim, uma multinacional de auto-ajuda". Tento descrever alguns contextos favoráveis ao uso dessa literatura em Grün (2000).

38 Uso a figura jurídica aparentemente anacrônica do "capital-indústria" justamente para lembrar esse constante trabalho de renomeação de velhas práticas que, aos meus olhos, é uma das características marcantes do embate cultural por que estamos passando. Procuro explorar essa faceta em Grün (2000). 


\section{Referências bibliográficas}

BIRNBAUM, Pierre. 1979. Le peuple et le gros: histoire d'un mythe. Paris: Grasset.

BOLTANSKI, Luc. 1982. Les cadres: la formation d'un groupe social. Paris: Éditions de Minuit.

_ e CHIAPELLO, Eve. 1999. Le nouvel esprit du capitalisme. Paris: Gallimard.

BOLTANSKI, Luc e THÉVENOT, Laurent. 1991. De la justification: les économies de la grandeur. Paris: Gallimard.

BOURDELAIS, Patrice. 1997. L'âge de la vieillesse: histoire du vieillissement de la population. Paris: Éditions Odile Jacob.

BOURDIEU, Pierre. 1997. Méditations pascaliennes. Paris: Seuil.

.2000. Les structures sociales de l'économie. Paris: Seuil.

CALLON, Michel (ed.). 1998. The laws of the markets. Oxford/Malden, MA: Blackwell Publishers/Sociological Review.

CASTEL, Robert. 1995. Les métamorphoses de la question sociale: une chronique du salariat. Paris: Fayard.

CASTELLS, Manuel. 1996. The rise of the network society. Cambridge, MA: Blackwell Publishers.

DEZALAY, Yves. 1994. “Technological warfare: the battle to control the mergers and acquisitions market in Europe". In: D. Sugarman e Y. Dezalay (eds.), Professional competition and professional power. London: Routledge. pp. 77-103.

DOUGLAS, Mary. 1996. Thought styles: critical essays on good taste. London/Thousand Oaks, CA: Sage. e NEY, Steve. 1998. Missing persons: a critique of the social sciences.
Berkeley/New York: University of California Press/Russell Sage Foundation.

ELIAS, Norbert. 1974. La société de cour. Paris: Calmann-Lévy.

FAMA, Eugene. 1980. "Agency problems and the theory of firm". Journal of Political Economy, 88(2):288-307.

FLIGSTEIN, Neil e FRIEDLAND, Robert. 1995. "Theoretical and comparative perspectives on corporate governance". Annual Review of Sociology, 21:21-43.

GOODY, Jack. 1997. Representations and contradictions: ambivalence towards images, theatre, fiction, relics, and sexuality. Cambridge, MA: Blackwell Publishers.

GRÜN, Roberto. 1986. "Taylorismo e fordismo no trabalho bancário: agentes e cenários". Revista Brasileira de Ciências Sociais, 1(2):13-27.

. 1995. A revolução dos gerentes brasileiros. São Carlos, SP: EdUFSCar. . 1998. "A classe média no mundo do neoliberalismo". Tempo Social, 10:143-164.

. 1999. "Modelos de empresa, modelos de mundo: sobre algumas características culturais da nova ordem econômica e da resistência a ela". Revista Brasileira de Ciências Sociais, 14(41):121-140.

_ . 2000. "Em busca da nova pequena burguesia brasileira". Dados, 43(2): 345-372.

.2003. " : Atores e ações na construção da governança corporativa brasileira". Revista Brasileira de Ciências Sociais, 18.

HACKING, Ian. 1999. The social construction of what? Cambridge, MA: Harvard University Press. 
HIRSCHFELD, Lawrence. 1994. "Is the acquisition of social categories based on domain-specific competence or on knowledge transfer?" In: L. A. Hirschfeld e S. A. Gelman (eds.), Mapping the mind: domain specificity in cognition and culture. Cambridge/New York: Cambridge University Press. pp. 201-232. e GELMAN, S. A. (eds.). 1994. Mapping the mind: domain specificity in cognition and culture. Cambridge/ New York: Cambridge University Press.

HOPWOOD, Anthony e MILLER, Peter. 1994. Accounting as social and institutional practice. Cambridge/New York: Cambridge University Press.

LAKOFF, George. 1996. Moral politics: what conservatives know that liberals don't. Chicago: The University of Chicago Press.

LEVY, Maristela. 1977. História da bolsa de valores. Rio de Janeiro: IBMEC.

MACKENZIE, Donald e MILLO, Yuval. no prelo. "Negotiating a market, performing theory: the historical sociology of a financial derivatives exchange". American Journal of Sociology.

MENGER, Pierre. 1997. La profession de comédien: formations, activités et carrières dans la démultiplication de soi. Paris: Ministère de la Culture et de la Communication/Département des Études et de la Prospective/ Diffusion La Documentation Française.

NIKONOFF, Jacques. 1999. La comédie des fonds de pension: une faillite intellectuelle. Paris: Arléa.

ORLÉAN, André. 1999. Le pouvoir de la finance. Paris: Éditions Odile Jacob. PAUGAM, Serge. 1994. La disqualification sociale: essai sur la nouvelle pauvreté. Paris: Presses Universitaires de France.
PUTNAM, Robert et alii. 1993. Making democracy work: civic traditions in modern Italy. Princeton, NJ: Princeton University Press.

RIEDER, Jonathan. 1990. “Rhetoric of reason, rhetoric of passion: sociolinguistic aspects of instrumental and expressive rhetorics". Rationality and Society, 2(2):190-213.

RINGER, Fritz. 1997. Max Weber's methodology: the unification of the cultural and social sciences. Cambridge, MA: Harvard University Press.

SAES, Flavio. 1986. A grande empresa de serviços públicos na economia cafeeira 1850-1930. São Paulo: Editora Hucitec.

SCHULZ, John. 1996. A crise financeira da abolição: 1875-1901. São Paulo: Edusp/Instituto Fernand Braudel. TANNURI, Luiz. 1981. O encilhamento. São Paulo: Hucitec.

TAUNAY, Alfredo. 1923 [1893]. O encilhamento. São Paulo: Companhia Melhoramentos.

THOMPSON, Edward. 1997. "The pyrrhic victory of gentlemanly capitalism: the financial elite of the City of London, 1945-90". Journal of Contemporary History, 32(3):283-304.

.1998. Costumes em comum: estudos sobre a cultura popular tradicional. São Paulo: Companhia das Letras.

USEEM, Michael. 1984. The Inner Circle: large corporations and the rise of business political activity in the U.S and U.K. New York: Oxford University Press.

1993. Executive defense: shareholder power and corporate reorganization. Cambridge, MA: Harvard University Press.

.1996. Investor capitalism: how money managers are changing the face of corporate America. New York: Basic Books. 


\section{Resumo}

$\mathrm{O}$ artigo trata do tema dos fundos de pensão brasileiros como um processo de construção social. Pretende mostrar como as transformações sofridas por estas entidades nos últimos dez anos refletem uma lógica social segundo a qual a definição de seu "real significado" se torna objeto de disputa por parte de diversos agentes coletivos. Esses agentes são os seus dirigentes tradicionais, os quadros financeiros que cresceram, grosso modo, durante os mandatos de FHC, e os dirigentes sindicais que, tendo decaído em importância com a queda da inflação no mesmo período, tentaram reconverter-se na administração das entidades. Na primeira parte do texto, apresenta-se um apanhado da história recente dos fundos. Na segunda, ensaia-se uma discussão teórica que propõe estabelecer os sentidos sociais da disputa e suas conseqüências para o entendimento da cena econômica brasileira contemporânea.

Palavras-chave Fundos de Pensão; Neoliberalismo; Sindicalismo; Classes Médias; Governança Corporativa

\section{Abstract}

The article deals with the issue "Brazilian pension funds" as a social construction process. The aim is to show how their recent changes may be understood as resulting from a fierce struggle among three groups of social agents, each one of them trying to establish their "real meaning". The agents are the traditional managers, the new "Chicago boys", and some former unions leaders put out of the show as a by-product of the 90's monetary stabilization, trying to make a new way as pension funds managers. In the first part we have some remarks on the Brazilian's pension funds recent history. The second part is dedicated to an approach of the subject as a path for the development of some theoretical consequences for the understanding of the recent Brazilian economic and social landscape.

Key words Pension Funds; Neo-liberalism; Unions; Middle Classes; Corporate Governance 